\title{
Effect of Bio-fertilizers and Inorganic Manures on Flowering and Yield of Chrysanthemum (Dendranthema grandiflora Tzvelev) cv. Haldighati
}

\author{
Satish Kumar Pandey, V.M. Prasad, S. Saravanan and Anil Kumar* \\ Department of Horticulture, SHUATS, Allahabad, U.P. 211007, India \\ *Corresponding author
}

\begin{abstract}
A B S T R A C T
Keywords

Azospirillum,

Chrysanthemum,

Nitrogen,

Phosphorus, Potash and PSB

Article Info

Accepted:

12 November 2018

Available Online:

10 December 2018

An field experiment was conducted to know the Effect of bio fertilizers and inorganic manures on plant flowering and yield of chrysanthemum (Chrysanthemum grandiflora) cv. Haldighati at the Department of Horticulture, Sam Higginbottom University of Agricultural Technology and Sciences (formerly Known as Allahabad Agriculture Institute Deemed University, AAI-DU) during winter season of 2014-15 and 2015-16. The experiment was laid out in Factorial Randomized Block Design with 15 treatments replicated thrice. Plants treated with $\mathrm{T}_{11} \mathrm{M}_{3} \mathrm{~F}_{3}$ (Azospirillum + PSB + NPK @ 150:100:100) proved to be the best treatment with respect to days to first flower bud initiation, days taken to 50 percent flowering, days taken to flowering, duration of flowering (days), number of flowers per plant, average weight of flowers ( $\mathrm{g}$ ), yield of flowers per plant $(\mathrm{g})$, yield of flower per plot $(\mathrm{kg})$ and yield of flower per hectare (tonnes). While the lowest values for all the above parameters were recorded with $T_{1} M_{1} F_{1}$ (Microbial inoculants $0+\mathrm{N}_{100}: \mathrm{P}_{50}: \mathrm{K}_{50}$ ) under the agro-climatic conditions of Allahabad.
\end{abstract}

\section{Introduction}

The flower farming industry is growing at an annual rate of 8-10 per cent. There are about 120 countries, which are actively involved in the Floriculture business. The area under flower cultivation in India is about 253.65 thousand hectares, which produces 1.652 million tonnes of loose flowers and 750.66 million cut flowers in 2011-12 (Anonymous, 2013). During 2012-13, India has provided 27,143.13 MT of floriculture products in the world. 423.42 crores area is under commercial cultivation in the areas of Tamilnadu, Karnataka, Andhra Pradesh, Maharashtra, Rajasthan, Madhya Pradesh and Gujarat.
Chrysanthemum (Chrysanthemum morifolium Ramat. Syn. Dendrendema grandiflora Tzvelev) is related to family Estacia. It is native to the northern hemisphere, mainly Europe and Asia, and it is believed that it came from China (Carter, 1990). There are approximately 160 species in the Chrysanthemum genus, in which the modern autumn flower perennial Chrysanthemum morifolium is the most important (Lion, 2006). It is a very attractive and attractive short day plant.

Bio-fertilizers are low cost, renewable sources of plant nutrients which supplement chemical fertilizers. These are nothing but selected 
strains of beneficial soil microorganisms cultured in the laboratory and packed in a suitable carrier. They can be used either for seed treatment or soil application. Biofertilizers generate plant nutrients like nitrogen and phosphorous through their activities in the soil or rhizosphere and make available to plants in a gradual manner. Bio fertilizers are gaining momentum recently due to the increasing emphasis on maintenance of soil health, minimize environmental pollution and cut down on the use of chemicals in agriculture. In rain fed agriculture, these inputs gain added importance in view of their low cost, as most of the farmers are small and marginal and cannot afford to buy expensive chemical fertilizers. Bio-fertilizers are also ideal input for reducing the cost of cultivation and for practising organic farming (Kumari et al., 2015).

Phosphate solubilizing Bacteria (PSB) are a group of beneficial bacteria capable of hydrolyzing organic and inorganic phosphorus from insoluble compounds. Some PSB produce phosphatase like phytase that hydrolyse organic forms of phosphate compounds efficiently. The use of phosphate solubilizing bacteria as inoculants simultaneously increases $\mathrm{P}$ uptake by the plant and crop yield. Strains from the genera Pseudomonas, Bacillus and Rhizobium are among the most powerful phosphate solubilizers. Azospirillum helps improving fertility of soil and help plant growth by increasing the number and biological activity of desired microorganisms in the root environment that increase $15-20 \%$ yield. Azospirillum directly fix $25-40 \mathrm{~kg}$ of $\mathrm{N} / \mathrm{ha}$ in the soil and save 15-20 kg of urea.

\section{Materials and Methods}

The present investigation was carried out under Allahabad agro-climatic condition at the experimental field of the Department of Horticulture, Sam Higginbottom University of
Agricultural, Technology and Sciences (Formerly Known as Allahabad Agriculture Institute Deemed University, AAI-DU) Allahabad, U.P. during September 2014 to February 2015 and September 2015 to February 2016. The soil of the experimental area was a fairly level land with sandy loam soil with uniform fertility status with low clay and high sand percentage with high PH (7.2) and soil moderately fertile. The soil of the experimental plot was well prepared by repeated ploughing followed by planking to obtain a fine tilth. The soil ploughed 4 times by cultivator, harrowed, levelled and the weeds were manually uprooted from experimental field as per requirement. Twenty five days old seedlings with 3-5 leaves were transplanted in the main field. Each plot contained 9 seedlings at the spacing of $60 \times 60$ $\mathrm{cm}$. All the different combination of biofertilizers and inorganic manures treatments viz.; $\mathrm{T}_{0}$ Control $\left(\mathrm{M}_{0} \mathrm{~F}_{1}\right.$-Microbial inoculants 0 $+\mathrm{N} 100: \mathrm{P} 50: \mathrm{K} 50) ; \mathrm{T}_{1} \mathrm{M}_{1} \mathrm{~F}_{1}$-Azospirillum + N100:P50:K50; $\quad \mathrm{T}_{2} \quad \mathrm{M}_{2} \mathrm{~F}_{1}$-PSB + N100:P50:K50; $\mathrm{T}_{3} \mathrm{M}_{3} \mathrm{~F}_{1}$-Azospirillum + PSB $+\quad \mathrm{N} 100: \mathrm{P} 50: \mathrm{K} 50 ; \quad \mathrm{T}_{4} \quad \mathrm{M}_{0} \mathrm{~F}_{2}$-Microbial inoculants $0+\mathrm{N} 125: \mathrm{P} 75: \mathrm{K} 75 ; \mathrm{T}_{5} \mathrm{M}_{1} \mathrm{~F}_{2^{-}}$ Azospirillum + N125:P75:K75; $\mathrm{T}_{6} \mathrm{M}_{2} \mathrm{~F}_{2}-\mathrm{PSB}$ + N125:P75:K75; T7 $\mathrm{M}_{3} \mathrm{~F}_{2}$-Azospirillum + $\mathrm{PSB}+\mathrm{N} 125: \mathrm{P} 75: \mathrm{K} 75 ; \mathrm{T}_{8} \mathrm{M}_{0} \mathrm{~F}_{3}$-Microbial inoculants $0+$ N150:P100:K100; $\mathrm{T}_{9} \mathrm{M}_{1} \mathrm{~F}_{3}-$ Azospirillum + N150:P100:K100; $\mathrm{T}_{10} \mathrm{M}_{2} \mathrm{~F}_{3}-$ $\mathrm{PSB}+\mathrm{N} 150: \mathrm{P} 100: \mathrm{K} 100 ; \quad \mathrm{T}_{11} \mathrm{M}_{3} \mathrm{~F}_{3^{-}}$ Azospirillum + PSB + N150:P100:K100; $\mathrm{T}_{12}$ $\mathrm{M}_{0} \mathrm{~F}_{4}$-Microbial inoculants $0+$ N175:P125:K125; $\mathrm{T}_{13} \quad \mathrm{M}_{1} \mathrm{~F}_{4}$-Azospirillum + N175:P125:K125; $\quad \mathrm{T}_{14} \quad \mathrm{M}_{2} \mathrm{~F}_{4}$-PSB + N175:P125:K125 and $\mathrm{T}_{15} \quad \mathrm{M}_{3} \mathrm{~F}_{4}$-Azospirillum + PSB + N175:P125:K125 are randomly arranged and observations recorded at regular intervals from the experimental field. The critical difference values were calculated at 5 percent level of significance. The data were subjected to Fisher's method of analysis of variance (ANOVA) as outlined by Panse and Sukhatme (1985). 


\section{Results and Discussion}

The data pertaining to various flowering and flower yield parameters viz., days taken to first flower bud initiation, days taken to 50 percent flowering, days taken to flowering, duration of flowering (days), number of flowers per plant, average weight of flowers (g), yield of flowers per plant $(\mathrm{g})$, yield of flower per plot $(\mathrm{kg})$ and yield of flower per hectare (tonnes) clearly indicate that the plants showed differential response towards different levels of bio fertilizers and inorganic manures and their interaction.

\section{Effect on flowering parameters}

Perusal from Table 1 reveals that the days taken to first flower bud initiation in inorganic manures $\mathrm{F}_{1} \quad(100: 50: 50 \quad \mathrm{NPK})$ showed minimum (64.19) and maximum (65.39) was recorded by the $F_{3} \quad(150: 100: 100$ NPK). Among the level of microbial, the lowest days taken to first flower bud initiation (62.24) was noticed in microbial with $\mathrm{M}_{0}$, while the highest (67.03) was observed with $\mathrm{M}_{3}$ (Azospirillum + PSB). There existed a significant interaction between inorganic manures and microbial for days taken to first flower bud initiation. The statistical analysis of days taken to 50 percent flowering, data indicates that there was significant difference among the treatments. Similarly, the inorganic manures $F_{1} \quad(100: 50: 50 \quad$ NPK) showed significantly maximum days taken to 50 percent flowering (75.42) and minimum (73.41) days taken to 50 percent flowering was recorded by the inorganic manures in $\mathrm{F}_{3}$ (150:100:100 NPK). Among the level of microbial, the highest days taken to 50 percent flowering (77.30) was noticed in the microbial with $\mathrm{M}_{0}$, while the lowest days taken to 50 percent flowering (72.32) was observed with $\mathrm{M}_{3}$ (Azospirillum $+\mathrm{PSB}$ ). There existed a significant interaction between inorganic manures and microbial for days taken to 50 percent flowering. Significantly the maximum days taken to flowering (81.51) was found in the inorganic manures $F_{1}(100: 50: 50$ NPK) and minimum (80.53) days taken to flowering was recorded by the inorganic manure in $\mathrm{F}_{3}$ (150:100:100 NPK). Among the level of microbial, the highest days taken to flowering (83.04) was noticed in the microbial with $\mathrm{M}_{0}$, while the lowest days taken to flowering (78.86) was observed with $\mathrm{M}_{3}$ (Azospirillum + PSB). There existed a significant interaction between inorganic manures and microbial for days taken to flowering. The better efficiency in combination with inorganic fertilizers and organic manure, the enhanced photosynthetic activity due to Azotobactor inoculation might have favoured an increased accumulation of dry matter and also efficient partitioning of photosynthates towards the sink Kumar et al., (2006). Also the similar finding was reported by Padaganur et al., (2005).

\section{Effect on flower yield parameters}

Perusal from Table 2 reveals that the number of flowers per plant in inorganic manures $\mathrm{F}_{3}$ (150:100:100 NPK) showed maximum (37.52) and minimum (35.93) was recorded by the $F_{1}$ (100:50:50 NPK). Among the level of microbial, the highest number of flowers per plant (38.39) was noticed in microbial with $\mathrm{M}_{3}$ (Azospirillum + PSB), while the lowest (34.63) was observed with $\mathrm{M}_{0}$. There existed a significant interaction between inorganic manures and microbial for number of flowers per plant. The statistical analysis of average weight of flower, data indicates that there was significant difference among the treatments. Similarly, the inorganic manures $\mathrm{F}_{3}$ (150:100:100 NPK) showed significantly maximum average weight of flower (3.21) and minimum (3.09) was recorded by the inorganic manures in $F_{1}(100: 50: 50$ NPK). Among the level of microbial, the highest average weight of flower (3.26) was noticed in the microbial with $\mathrm{M}_{3}$ (Azospirillum + PSB), while the lowest average weight of flower (3.01) was observed with $\mathrm{M}_{0}$. 
Table.1 Effect of bio-fertilizers and inorganic manures on flowering parameters of chrysanthemum cv. Haldighati

\begin{tabular}{|c|c|c|c|c|c|c|c|c|c|c|c|c|c|c|c|}
\hline \multirow{3}{*}{$\begin{array}{l}\text { Microbial } \\
\text { inoculants }\end{array}$} & \multicolumn{5}{|c|}{ Days taken to first flower bud initiation } & \multicolumn{5}{|c|}{ Days taken to 50 percent flowering } & \multicolumn{5}{|c|}{ Days taken to flowering } \\
\hline & \multicolumn{4}{|c|}{ Fertilizes } & \multirow[b]{2}{*}{ Mean } & \multicolumn{4}{|c|}{ Fertilizes } & \multirow[b]{2}{*}{ Mean } & \multicolumn{4}{|c|}{ Fertilizes } & \multirow[b]{2}{*}{ Mean } \\
\hline & $\mathbf{F}_{1}$ & $\mathbf{F}_{2}$ & $\mathbf{F}_{3}$ & $\mathbf{F}_{4}$ & & $\mathbf{F}_{1}$ & $\mathbf{F}_{2}$ & $\mathbf{F}_{3}$ & $\mathbf{F}_{4}$ & & F1 & $\mathrm{F} 2$ & F3 & $\mathrm{F} 4$ & \\
\hline $\mathbf{M}_{0}$ & 67.98 & 67.23 & 66.17 & 66.72 & 67.03 & 78.00 & 77.65 & 76.45 & 77.12 & 77.30 & 83.72 & 83.15 & 82.50 & 82.80 & 83.04 \\
\hline $\mathrm{M}_{1}$ & 65.72 & 65.20 & 64.35 & 64.78 & 65.01 & 75.90 & 75.47 & 74.62 & 75.05 & 75.26 & 82.07 & 81.70 & 80.70 & 81.15 & 81.40 \\
\hline $\mathrm{M}_{2}$ & 64.12 & 62.77 & 61.58 & 63.28 & 62.93 & 74.07 & 72.70 & 71.52 & 73.20 & 72.75 & 80.35 & 79.33 & 78.25 & 79.62 & 79.39 \\
\hline $\mathrm{M}_{3}$ & 63.75 & 62.33 & 60.90 & 61.98 & 62.24 & 73.73 & 72.28 & 71.05 & 71.78 & 72.32 & 79.93 & 78.98 & 77.93 & 78.60 & 78.86 \\
\hline Mean & 65.39 & 64.38 & 63.25 & 64.19 & 64.30 & 75.42 & 74.52 & 73.41 & 74.29 & 74.41 & 81.51 & 80.78 & 79.84 & 80.53 & 80.66 \\
\hline Factor & CV & $\begin{array}{l}\text { F- } \\
\text { test }\end{array}$ & $\begin{array}{l}\text { S. } \\
\text { Ed. }( \pm)\end{array}$ & $\begin{array}{l}\text { CD } \\
(5 \%)\end{array}$ & & CV & F-test & $\begin{array}{l}\text { S. } \\
\text { Ed. }( \pm)\end{array}$ & $\begin{array}{l}\text { CD } \\
(5 \%)\end{array}$ & & $\mathrm{CV}$ & F-test & $\begin{array}{l}\text { S. } \\
\text { Ed. }( \pm)\end{array}$ & $\begin{array}{l}\mathrm{CD} \\
(5 \%)\end{array}$ & \\
\hline $\mathrm{M}$ & 0.54 & $S$ & 0.10 & 0.20 & & 0.49 & $\mathrm{~S}$ & 0.10 & 0.21 & & 0.55 & $\mathrm{~S}$ & 0.13 & 0.26 & \\
\hline $\mathrm{F}$ & & $\mathrm{S}$ & 0.10 & 0.20 & & & $\mathrm{~S}$ & 0.10 & 0.21 & & & $\mathrm{~S}$ & 0.13 & 0.26 & \\
\hline $\mathrm{M} \times \mathrm{F}$ & & $\mathrm{S}$ & 0.20 & 0.40 & & & $\mathrm{~S}$ & 0.20 & 0.42 & & & $\mathrm{~S}$ & 0.26 & 0.52 & \\
\hline
\end{tabular}


Int.J.Curr.Microbiol.App.Sci (2018) 7(12): 1696-1703

Table.2 Effect of bio-fertilizers and inorganic manures on floral parameters of chrysanthemum cv. Haldighati

\begin{tabular}{|c|c|c|c|c|c|c|c|c|c|c|c|c|c|c|c|}
\hline \multirow{3}{*}{$\begin{array}{l}\text { Microbial } \\
\text { inoculants }\end{array}$} & \multicolumn{5}{|c|}{ Number of flowers per plant } & \multicolumn{5}{|c|}{ Average weight of flower $(\mathrm{g})$} & \multicolumn{5}{|c|}{ Flower yield per plant $(\mathrm{g})$} \\
\hline & \multicolumn{4}{|c|}{ Fertilizes } & \multirow[b]{2}{*}{ Mean } & \multicolumn{4}{|c|}{ Fertilizes } & \multirow[b]{2}{*}{ Mean } & \multicolumn{4}{|c|}{ Fertilizes } & \multirow[b]{2}{*}{ Mean } \\
\hline & $\mathbf{F}_{1}$ & $\mathbf{F}_{2}$ & $\mathbf{F}_{3}$ & $\mathbf{F}_{4}$ & & $\mathbf{F}_{1}$ & $\mathbf{F}_{2}$ & $\mathbf{F}_{3}$ & $\mathbf{F}_{4}$ & & $\mathbf{F}_{1}$ & $\mathbf{F}_{2}$ & $\mathbf{F}_{3}$ & $\mathbf{F}_{4}$ & \\
\hline $\mathrm{M}_{0}$ & 33.78 & 34.53 & 35.27 & 34.93 & 34.63 & 2.96 & 3.00 & 3.06 & 3.04 & 3.01 & 99.90 & 103.51 & 107.79 & 106.08 & 104.32 \\
\hline $\mathrm{M}_{1}$ & 35.63 & 35.93 & 36.60 & 36.28 & 36.11 & 3.08 & 3.10 & 3.14 & 3.13 & 3.11 & 109.82 & 111.49 & 115.13 & 113.48 & 112.48 \\
\hline $\mathrm{M}_{2}$ & 36.98 & 38.02 & 38.98 & 37.67 & 37.91 & 3.16 & 3.22 & 3.30 & 3.18 & 3.20 & 117.11 & 122.39 & 128.64 & 120.01 & 122.03 \\
\hline $\mathrm{M}_{3}$ & 37.32 & 38.40 & 39.22 & 38.63 & 38.39 & 3.19 & 3.24 & 3.34 & 3.27 & 3.26 & 118.98 & 124.48 & 131.00 & 126.59 & 125.26 \\
\hline Mean & 35.93 & 36.72 & 37.52 & 36.88 & 36.76 & 3.09 & 3.14 & 3.21 & 3.16 & 3.15 & 111.45 & 115.46 & 120.64 & 116.54 & 116.02 \\
\hline Factor & $\mathbf{C V}$ & $\begin{array}{l}\text { F- } \\
\text { test }\end{array}$ & $\begin{array}{l}\text { S. } \\
\text { Ed. }( \pm)\end{array}$ & $\begin{array}{l}\text { CD } \\
(5 \%)\end{array}$ & & $\mathbf{C V}$ & F-test & $\begin{array}{l}\text { S. } \\
\text { Ed. }( \pm)\end{array}$ & $\begin{array}{l}\text { CD } \\
(5 \%)\end{array}$ & & CV & F-test & $\begin{array}{l}\text { S. } \\
\text { Ed. }( \pm)\end{array}$ & $\begin{array}{l}\text { CD } \\
(5 \%)\end{array}$ & \\
\hline $\mathrm{M}$ & 1.05 & $\mathrm{~S}$ & 0.11 & 0.22 & & 1.07 & $S$ & 0.01 & 0.02 & & 1.50 & $\mathrm{~S}$ & 0.50 & 1.00 & \\
\hline $\mathrm{F}$ & & $\mathrm{S}$ & 0.11 & 0.22 & & & $S$ & 0.01 & 0.02 & & & $\mathrm{~S}$ & 0.50 & 1.00 & \\
\hline $\mathrm{M} \times \mathrm{F}$ & & $\mathrm{S}$ & 0.22 & 0.44 & & & $S$ & 0.02 & 0.04 & & & $\mathrm{~S}$ & 1.00 & 2.00 & \\
\hline
\end{tabular}


Int.J.Curr.Microbiol.App.Sci (2018) 7(12): 1696-1703

\begin{tabular}{|c|c|c|c|c|c|c|c|c|c|c|c|}
\hline \multirow{3}{*}{$\begin{array}{l}\text { Microbial } \\
\text { inoculants }\end{array}$} & \multicolumn{6}{|c|}{ Yield of flower per plot $(\mathrm{kg})$} & \multicolumn{5}{|c|}{ Yield of flower per hectare (tones) } \\
\hline & \multicolumn{4}{|c|}{ Fertilizes } & \multirow[b]{2}{*}{ Mean } & \multirow[b]{2}{*}{ Mean } & \multicolumn{4}{|c|}{ Fertilizes } & \multirow[b]{2}{*}{ Mean } \\
\hline & $\mathbf{F}_{1}$ & $\mathbf{F}_{2}$ & $\mathbf{F}_{3}$ & $\mathbf{F}_{4}$ & & & $\mathbf{F}_{1}$ & $\mathbf{F}_{2}$ & $\mathbf{F}_{3}$ & $\mathbf{F}_{4}$ & \\
\hline $\mathrm{M}_{0}$ & 1.20 & 1.24 & 1.29 & 1.27 & 1.25 & 3.01 & 11.10 & 11.50 & 11.98 & 11.79 & 11.59 \\
\hline $\mathrm{M}_{1}$ & 1.32 & 1.34 & 1.38 & 1.36 & 1.35 & 3.15 & 12.20 & 12.39 & 12.79 & 12.61 & 12.50 \\
\hline $\mathrm{M}_{2}$ & 1.41 & 1.47 & 1.54 & 1.44 & 1.46 & 3.27 & 13.01 & 13.60 & 14.29 & 13.33 & 13.55 \\
\hline $\mathrm{M}_{3}$ & 1.43 & 1.49 & 1.57 & 1.52 & 1.50 & 3.33 & 13.22 & 13.83 & 14.56 & 14.07 & 13.92 \\
\hline Mean & 1.34 & 1.38 & 1.44 & 1.40 & 1.39 & 3.19 & 12.38 & 12.83 & 13.40 & 12.95 & 12.90 \\
\hline Factor & CV & F-test & $\begin{array}{l}\text { S. } \\
\text { Ed. }( \pm)\end{array}$ & $\begin{array}{l}\text { CD } \\
(5 \%)\end{array}$ & & & CV & F-test & $\begin{array}{l}\text { S. } \\
\text { Ed.( }( \pm)\end{array}$ & $\begin{array}{l}\text { CD } \\
(5 \%)\end{array}$ & \\
\hline $\mathrm{M}$ & 1.47 & $\mathrm{~S}$ & 0.01 & 0.02 & & & 1.50 & $\mathrm{~S}$ & 0.05 & 0.11 & \\
\hline F & & $S$ & 0.01 & 0.02 & & & & S & 0.05 & 0.11 & \\
\hline $\mathrm{M} \times \mathrm{F}$ & & $\mathrm{S}$ & 0.02 & 0.04 & & & & $S$ & 0.10 & 0.22 & \\
\hline
\end{tabular}


There existed a significant interaction between inorganic manures and microbial for average weight of flower. Significantly the maximum flower yield per plant (120.64) was found in the inorganic manures $\mathrm{F}_{3}$ (150:100:100 NPK) and minimum (111.45) flower yield per plant was recorded by the inorganic manures in $F_{1}(100: 50: 50 \mathrm{NPK})$. Among the level of microbial, the highest flower yield per plant (125.26) was noticed in the microbial with $\mathrm{M}_{3}$ (Azospirillum + PSB), while the lowest flower yield per plant (104.32) was observed with $\mathbf{M}_{0}$. There existed a significant interaction between inorganic manures and microbial for flower yield per plant. In case of yield of flower per plot in inorganic manures $\mathrm{F}_{3}$ (150:100:100 NPK) showed maximum (1.44) and minimum (1.34) was recorded by the $F_{1}(100: 50: 50$ NPK). Among the level of microbial, the highest yield of flower per plot (1.50) was noticed in microbial with $\mathrm{M}_{3}$ (Azospirillum $+\mathrm{PSB}$ ), while the lowest (1.25) was observed with $\mathrm{M}_{0}$. There existed a significant interaction between inorganic manures and microbial for number of flowers per plant. Similarly, the yield of flower per hectare in inorganic manures $F_{3} \quad(150: 100: 100 \quad$ NPK) showed significantly maximum (13.40) and minimum (12.38) was recorded by the inorganic manures in $F_{1}(100: 50: 50$ NPK). Among the level of microbial, the highest average weight of flower (13.92) was noticed in the microbial with $\mathrm{M}_{3}$ (Azospirillum $+\mathrm{PSB}$ ), while the lowest average weight of flower (11.59) was observed with $\mathbf{M}_{0}$. There existed a significant interaction between inorganic manures and microbial for average weight of flower. The increase in number of florets per flower on application of Azo+PSB $+50 \% \mathrm{VC}$ equivalent to $\mathrm{RD}^{\prime} \mathrm{N}^{\prime}+50 \%$ RDF (T12) might be due to the combined beneficial effect of organic manures, bio-fertilizers and RDF. Similar results have been reported by Verma et al., (2011) and Laishram et al., (2013) in chrysanthemum. The improved flower yield per plant with integrated nutrient management treatments may be assigned to better translocation of nutrients to the flowers brought about by application of inoculants like PSB and Azospirillum (Laishram et al., 2013). Similar results have also been reported by Chandrikapure et al., (1999) in marigold, Kulkarni et al., (1996) in China aster and Kusuma (2001) in golden rod.

\section{Acknowledgements}

The author is grateful to the department of Horticulture, SHUATS, Allahabad for the facilities and financial support to the present research work.

\section{References}

Anonymous, 2013. Indian Horticulture Database. National Horticulture Board, Ministry of Agriculture, Government of India, Gurgaon, Haryana.

Carter, G.D., 1990. Introduction to Floriculture (ed. R.A. Larson), Academic Press, New York.

Chandrikapure, K.R., Sadawarte, K.T., Panchabh, D.M. and Shelke, B.D. 1999. Effect of bioinoculants and graded doses of nitrogen on growth and flower yield of marigold (Tagetes erecta L.). Orissa J. of Hort., 27(2): 31-34.

Kulkarni, B.S., Nalawadi, U.G. and Giraddi, R.S. 1996. Effect of vermicompost and vermiculture on growth and yield of china aster (Callistephus chinensis Nees) cv. Ostrich plum mixed. South Indian Hort., 44(1\&2): 33-35.

Kumar M, Singh S, Sharma SK, Dahiya DS, Beniwal LS.2006. Effect of biofertilizers on growth and flowering of marigold Cv. Pusa Narangi. Haryana J. Hort. Sci., 35(1 \& 2):71-72.

Kumari Supriya, Singh J. and Masih H. 2015. Isolation and identification of free living nitrogen fixer and 
Phosphobacteria from the partial flood affected area of Bihar and its effect on growth and yield of paddy (Oryza sativa L.) In: Res. Environ. Life Sci., 8(1):8386.

Kusuma, G. 2001. Effect of organic and inorganic fertilizers on growth, yield and quality of golden rod. M.Sc.(Ag.) thesis, UAS, Dharwad, Karnataka.

Laishram, N. 2011. Studies on integrated nutrient management for commercial flower production of chrysanthemum (Dendranthema grandiflora Tzvelev.). M.sc. (Ag.) Thesis. YSP Uni. of Hort. $\&$ For., Nauni, Solan.

Laishram, N., Dhiman, S.R., Gupta, Y. C., Bhardwaj, S. K and Singh, A. 2013. Microbial dynamics and physicochemical properties of soil in the rhizosphere of chrysanthemum (Dendranthema grandiflora) as influenced by Integrated Nutrient Management. Indian J. of Ag. Sci.,
83(4): 447-455.

Padaganur V.G., Mokashi A.N., Patil V.S. 2005. Flowering, flower quality and yield of tuberose (Polianthes tuberosa L.) as influenced by vermicompost, farmyard manure and fertilizers. Karnataka J. Agric. Sci., 18(3):729-734.

Panse, V.G. and Sukhatme, P.V. 1985. Statistical method for Agriculture Workers. ICAR, New Delhi.

Singh, A.K., 2006. Chrysanthemum. In: Flower Crops: Cultivation and Management. New India Publishing Agency, New Delhi, pp. 73-91.

Verma, S.K., Angadi, S.G., Patil, V.S., Mokashi, A.N., Mathad, J.C. and Mummigatti, U.V. 2011. Growth, yield and quality of chrysanthemum (Chrysanthemum morifolium Ramat.) cv. Raja as influenced by Integrated Nutrient Management. Karnataka $J$. Agri. Sci., 24(5): 681-683.

\section{How to cite this article:}

Satish Kumar Pandey, V.M. Prasad, S. Saravanan and Anil Kumar. 2018. Effect of Biofertilizers and Inorganic Manures on Flowering and Yield of Chrysanthemum (Dendranthema grandiflora Tzvelev) cv. Haldighati. Int.J.Curr.Microbiol.App.Sci. 7(12): 1696-1703. doi: https://doi.org/10.20546/ijcmas.2018.712.197 